\title{
Communication and Symbolic Capitalism. Rethinking Marxist Communication Theory in the Light of the Information Society
}

\section{George Pleios}

Associate Professor, University of Athens, Greece. gplios@media.uoa.gr

https://sites.google.com/site/georgepleioswebsite/

\begin{abstract}
Communication is examined in the realm of Marxist theory not as an autonomous social field, but as a component in the total social structure. It is argued that there was a shift from the initial Marxist idea of forms of communication as relations of production to communication as part of the superstructure, and that this view has prevailed in Marxist theory for a long period of time. In the work of later Marxists, we can spot a re-connection of communication with the capitalist mode of production, but not with the process of structuration and changing of relations of production. In my view, first we must connect these modifications in Marxist theory with the changes in the capitalist mode of production itself and secondly we must seek the role of communication primarily in the production process. We stress that at the end of the $19^{\text {th }}$ century there was a shift from extensive to intensive forms of surplus value which was tightly interconnected with the mass (enlarged) consumption of symbolic commodities and commodities - symbols as stimulus for the intensive production. In this way capitalism was transformed to symbolic capitalism. In the '60s, the symbolic logic of enlarged consumption led to the need for diverse and flexible production and therefore to the deep information - symbolic changes in technology and social organization of the labour. Thus the logic of consumption became the logic of production. This made possible on one hand the shrinkage of the enlarged consumption and on the other the high productivity of the economic systems. This was the rise of a new, deep symbolic capitalism, which made possible the social change without seizing the power. Therefore, the recent developments in the capitalist mode of production takes us back to the primary Marxist notion of communication forms as relations of production and make possible to change the laters by changing the first.
\end{abstract}

Keywords: Marxism, Capitalism, Symbolic Capitalism, Communication Theory, Mass Culture, Mass Production, Flexible Specialization, Post-Fordism, Enlarged Consumption, Cultural Industries, Consumer Capitalism, Information Society, Organization of Labor, New Technologies, Postmodernism, Social Change.

\section{Methodological Issues}

The main purpose of this article is not to examine the Marxist theory of communication as a specific social field, but to look into communication as a parameter in general Marxist social theory. In other words, this article aims to look into the structural role of communication on the basis of a base superstructure model of social organization with regard to its historical transformation and to different approaches in Marxist social theory. Therefore, it elaborates the discussion mainly between the approach of traditional Marxism and those of later schools of thought, both Marxist or any influenced by them in an effort to assess the development of the capitalist mode of production as a result of the key role of communication.

In my opinion we can draw a development of the Marxist concept of the relations between the capitalist mode of production and communication, in four steps or moments. At first (e.g. in "The German Ideology"), communication and the relations of production are identical. In the primary formulation, in the "German Ideology" (Marx and Engels 1978a, 67), the relations of production (or property relations) are characterized as "forms of communication". With this term, Marx and Engels aim to explain ideology, which they perceive as being equal to idealism, in relation to the mode of production and class relations. A certain degree or form of division of labour leads to a certain quality and quantity of distribution of the products of labour. In other words, the structure of distribution is connected to the division of labour within the production process. Certain social relations of production and distribution emanate from this division of labour and (Marx and Engels 1978a, 78). Marx and Engels understand relations of production as class/property relations on one hand, and as communication forms on the other.

As they note, "the production of ideas, of conceptions, of consciousness, is at first directly interwoven with the material activity and the material intercourse of men, the language of real life. Con- 
ceiving, thinking, the mental intercourse of men, appear at this stage as the direct efflux of their material behavior. The same applies to mental production as expressed in the language of politics, laws, morality, religion, metaphysics, etc., of a people. Men are the producers of their conceptions, ideas, etc. - real, active men, as they are conditioned by a definite development of their productive forces and of the intercourse corresponding to these, up to its furthest forms. Consciousness can never be anything else than conscious existence, and the existence of men is their actual lifeprocess" (Marx and Engels 1978a, 67-8).

Thus they understand relations of production as social relations within a broader context, where social interaction, the use of symbols in it and the ideas that derive from it or refer to that interaction are regarded as a whole. In this formulation, the "forms of communication" become a means of establishing, sustaining and changing the social relations of production, and vice versa, in connection to the division of labour. From this point of view, communication and symbolic structures are not only passive means but also an essential part of the social relations of production, especially in pre-capitalist societies. For example, Marx notes that Moses managed to establish new laws in favor of virtue, justice and morality because he grounded the new principles on land ownership (Marx 1983, 100). In other words, the answer to the question about the importance of forms of communication regarding the social relations of production and social organization depends on the division of labour and the overall mode of production overall.

In a second step/moment, Marx accepts that, communication and especially its ideational content are relatively separated from the relations of production, which are perceived to be class and property relations, and placed within the superstructure. "In the social production of their life, men enter into definite relations that are indispensable and independent of their will, relations of production which correspond to a definite stage of development of their material productive forces. The sum total of these relations of production constitutes the economic structure of society, the real foundation, on which rises a legal and political superstructure and to which correspond definite forms of social consciousness" (Marx and Engels 2001, 39).

Here, communication depends on and reflects what is taking place in the base, in class and property relations. According to Marx and Engels: "The ideas of the ruling class are in every epoch the ruling ideas, i.e. the class which is the ruling material force of society, is at the same time its ruling intellectual force. The class which has the means of material production at its disposal has control at the same time over the means of mental production, so that thereby, generally speaking, the ideas of those who lack the means of mental production are subject to it" (Marx and Engels 1978a, 94). This view can be interpreted, in two ways.

a. In a more instrumental approach, where it is accepted that the means of communication belong to those that own the means of production and thus use them "on purpose" to express their views in order to gain profit from this business or/and justify and maintain social inequality. The communication product (or text with semiotic terms) as merchandise, i.e. a product of commodity production, which is bought for money and is intended to satisfy certain needs. As Marx states: "beyond all commodity is an external object, something which with its attributes satisfies human needs. The nature of these needs, no matter their origin, for example stomach or imagination, does not change the nature of the work" (Marx and Engels 2001, 39 - 42; Marx 1979, 45). Marx and Engels also assert that those who own the means of production, also own the means of communication, which they use in order to maintain political and ideological control over society and preserve capitalist property and class relations. "The individuals composing the ruling class possess among other things consciousness, and therefore think. Insofar, therefore, as they rule as a class and determine the extent and compass of an epoch, it is selfevident that they do this in its whole range, hence among other things rule also as thinkers, as producers of ideas, and regulate the production and distribution of the ideas of their age: thus their ideas are the ruling ideas of the epoch" (Marx and Engels 1978a, 94)

b. The above mentioned statement can be interpreted in a more structural notion, one that asserts that those who own and control the means of production, may usually see their views being reflected in the products of communication Such an approach focuses mainly on the ideological aspects of communication content. "The ruling ideas are nothing more than the ideal expression of the dominant material relationships, the dominant material relationships grasped as ideas; hence of the relationships which make the one class the ruling one, therefore, the ideas of its dominance. The individuals composing the ruling class possess among other things consciousness, and therefore think. Insofar, therefore, as they rule as a class and determine the extent and compass of an epoch, it is self-evident that they do this in its whole range, 
hence among other things rule also as thinkers, as producers of ideas, and regulate the production and distribution of the ideas of their age: thus their ideas are the ruling ideas of the epoch" (Marx and Engels 1978a, 94). Communication (of ideas) reflects the social relations that exist in the base of a social structure, an idea supported by positivists according to Williams (Williams 2001, 153). The communication product is examined in its content as a whole of ideas. In this context, communication and communication products/commodities are becoming part of the superstructure.

Overall, in the second step of the evolution of the Marxist theory of communication, the latter is regarded more or less as an autonomous social field. Marx himself not only separates the superstructure from the structure, but also the idea of the "relative autonomy" between art and superstructure (Marx and Engels, 1975). Such a view has long dominated Marxist theory.

Thirdly, other Marxists have developed various notions of communication - production relations are discussed in phase two in a more systematic way and often separated from each other. At the same time, their accounts constitute different types of Marxism or (neo) Marxist communication theory. In my analysis, it is important to remember that what is under investigation in each case happens in tandem with the specific historical or spatio-temporal context of the communicative process.

For a long period of time, a distinct Marxist tradition was developed that was looking at communication as a cultural field, which reflects the broader structures of capitalist society in the form of ideas and discourses. Therefore it focused on the ideological aspects of communication content and practices (also mainly of the fictional types of content). Such an approach was undertaken by Marxist structuralism (Althusser 1990,69-95) and, in a different manner, by Soviet Marxism. Marxist structuralism does not focus on the process of production of cultural products or other goods and their relation to communication content and ideology; rather, it absorbs the relations of production in the communication content as the ruling classes' view of reality. The two aspects of cultural production (economic and communicative) were considered as structural parallels, which however are not essentially interconnected. The ideological function of cultural production, even if linked to its commodity character, preserves its autonomy and depends to a great degree on the cultural rules and the particular cultural field to which the product belongs - otherwise, the commodity function of the cultural product is absorbed by ideology. Whatever the case, the ideological function of communication is not connected organically to its economic role, being a special symbolic process. This particular Marxist approach is not related to my analysis of communication as a key component of the social structure.

Besides the above mentioned, mainly cultural approach, a different one has been developed in the realm of (neo) Marxism. It analyzes, in different ways and degrees, communication and its content in relation to the process of commodity production of symbolic and non-symbolic products, and the relations of production. Critical Theory, mostly Adorno, undertook a more structural sociophilosophical approach and investigated communication as a field which penetrated the industrial capitalist mode of production (and structures) that characterizes State Monopoly Capitalism (Horkheimer and Adorno 1986; Adorno and Horkheimer 1987, 219-243). Industrial production, hand in hand with commoditization, enters the communication field, but the problem is not technology because it is materialization of the capitalist mode of production. This on one hand leads to an extreme commoditization of communication products that eliminates their commercial character and on the other to the embodiment of the ruling classes' ideology in the content. The mass production of communication products leaves little room for alternative ideas. Adorno and Horkheimer underline that "Films and radio no longer need to present themselves as art. The truth that they are nothing but business is used as an ideology to legitimize the trash they intentionally produce. They call themselves industries and the published figures for their directors' incomes quell any doubts about the social necessity of their finished products" (Adorno and Horkheimer 2001, 72).

Beyond that, commoditized communication (e.g. advertisement) became a means that helps the circulation of industrial non-cultural commodities, which also dominate the everyday life of individuals. The consumption of communication products satisfies the needs of the routine reproduction of the labour force like the non-cultural ones. "Entertainment is the prolongation of work under late capitalism. It is sought by those who want to escape the mechanized labor process so that they can cope with it again. At the same time, however, mechanization has such power over leisure and its happiness, determines so thoroughly the fabrication of entertainment commodities, that the off-duty worker can experience nothing but afterimages of the work process itself" (Adorno and 
Horkheimer 2001, 82). Due to the embodied ideas and the commoditized form of their consumption, this leads to the integration of the working class in the system.

Thus communication serves the sustainment of the (Monopoly State) capitalist mode of production. In this way, Critical Theory does not focus only on the consequences of the capitalist mode of production on the autonomous superstructure, like Marxist structuralism does. Instead, it looks at the penetration of the capitalist mode of production in communication and its ideological and structural consequences, which results in the abolition of the autonomy of the superstructure - the base, thus, conquers and homogenizes the superstructure. For this reason, such an approach in the words of Garnham could be characterized as "economic determinism" in cultural and communication studies (Garnham, 1979) in contrast to the idealism of Marxist structuralism. But Critical Theory does not examine the role of communication in the formation of the State Monopoly Capitalist mode of production itself at the level of production (i.e. the role of consumed symbolic goods at the work place). It only examines the reproductive role of regarding the capitalist base as determining its contestation.

The propaganda model accepts a more instrumental version of the Marxist theory of communication. More precisely it informs the way in which the agents of capitalist cultural production embody the ruling ideas in the content (mainly the factual content) in order to fulfill economic as well as political goals. Thus the propaganda model focuses also on the process of production of communication commodities and their ideological content, on their political consequences, and thus the sustaining of capitalist economic and social relations, in close relation to the activity and objectives of those that own the means of cultural production (Herman and Chomsky 2001). In this manner, communication contributes to the sustaining of the capitalist mode of production not directly, but trough manufacturing consent in the political and ideological arena.

The "encoding/decoding" model connects organically a cultural and economic analysis of communication with the production and consumption (reading) moment of the communication process (Hall 1980). From this starting point, Critical Political Economy of Communication combines the Critical/theoretical analysis with the positive/empirical analysis of economic, cultural and political factors that determine communication products, and the field of communication as such, as part of the capitalist economy (Schiller 1973; Mosco 2009; Curran 1979; Golding and Murdock 2001). The industrial-capitalist manufacturing of communication products is regarded not as the core, but as part of the broader capitalist economy and structure of interests (Golding and Murdock 2001, 2628). Critical Political Economy examines the consequences of the capitalist mode of production for communication in a more complex and historical way. As Nicolas Garnham put it "... the superstructure/culture is and remains subordinate and secondary and the crucial questions are the relationship between, on the one hand, the mode of extraction and distribution of the material surplus, e.g. class relations and, on the other, the allocation of this material surplus within the superstructure, for instance, the problem of public expenditure among others" (Garnham 1979). Despite the importance of Critical Political Economy in understanding the complex role of economic, political and cultural mechanisms in the production of communication commodities (and their ideology) in lat capitalism, the question about the contribution of communication to the process of production of (non-communication) commodities and to the "division of labour" remains unanswered.

In general, in this third stage, communication is conceived as part of the superstructure and as a field of extension and penetration of the capitalist-industrial mode of production. In a nutshell, in the Marxist theory of communication, while the contribution of the capitalist mode of production in the communication field and the mode of communication has been under examination for long, the significance of (the mode of) communication in the production, not the circulation of commodities, the political, has not been enough analysed.

The later is a key issue in a fourth step or moment in the development of the Marxist Theory of Communication, which is indispensable from those Marxist theories of the third step that connect communication with the production process. Critical Theory is in my view a neomarxist approach that focuses extensively on the role of communication in sustaining and reproducing the (State Monopoly) capitalist mode of production. But, as I already mentioned, this is limited to the simple reproduction of the labour force just before it visits the workplace. Williams tended to treat the "base" as indispensable for certain superstructure elements, especially at the level of the work force (Williams 2001, 154-155). In his view: "If we have the broad sense of forces of production, we look at the whole question of the base differently, and we are then less tempted to dismiss it as superstructural, and in that sense as merely secondary certain vital productive social forces, which are in the broad sense, from the beginning basic" (Williams 2001, 155). Ezensberger investigates 
the organic role of communication in the sphere of production. It is argued that the means of communication are means of production (Ezensberger 1981). Finally, put in its historical context, one must reconfigure in Marxist terms Baudrillard's idea that the mode of production is a result of the communication mode and not the other way round (Baudrillard 1990, 112; Pleios 1993, 50-64). At this point, one should not leave aside Debord's theory, according to which the spectacle is the superior form of commodity production, exchange and consumption (Debord, 1986).

The connection of communication with the mode of production (and especially the relations of production) in the frame of the Marxist rationale can be seen into two ways. Firstly, communication is regarded as a process which is placed mostly in the sphere of commodity circulation, that is to say that it facilitates the sale of the product (for example as it happens with advertising or promoting a consumerist way of life (Marx and Horkheimer 2001; Fuchs 2010a).

Secondly, it can be argued that the economic role of communication is not limited only to the sphere of trade and consumption. In my opinion, communication can be regarded as a process that facilitates, strengthens or changes the capitalist mode of production in its core (the "division of labour"), beyond the sphere of cultural industries or cultural consumption alone. That perhaps could explain the modifications of the capitalist mode of production and the deeper role of communication and cultural industries the development of the capitalist mode of production.

My analysis is situated within this fourth step. I do not examine communication just as form of the superstructure which reflects and reproduces the base or as a field that penetrates the industrial capitalist mode of production or as a means that facilitates the circulation of goods. I explore the role of socially organized communication (including cultural industries) in the core of the capitalist mode of production, namely in the process of the production of goods (of non cultural industries) as well as in the structuration of relations of production. In other words, I examine communication as force of sustaining and changing the mode of production in its core, in the social relations of production at the workplace. This is not something that characterizes every form/stage of capitalism, but it is a historical result of the development of the capitalist mode of production. Hence, I accept that communication contributes not only to the realization of the surplus value that has been created in production, or to the simple reproduction of the workforce. My starting point is that via consumption certain attributes (values and norms) are created among the workforce that renders them more productive, so that surplus value is increased during the process of production under specific organization of the work. This second stance is feasible in the frame of consumer capitalism.

Enlarged consumption does not only help the consumption of commodities, but also reconstructs the labor force in such a way that it becomes more productive and consequently increases its productivity, which in other words decreases the working time needed for its own reproduction and as a result contributes to the increase of surplus value (Pleios 1993, 56-58). This approach is not unknown, but has been proposed with the help of other terms. Human capital theory, for example, which is a functionalist theory, adopts a similar approach (Schultz 1961). In the present article, this second spectrum of analysis is followed, focusing on the social-symbolic construction and not the biological-bodily manufacture and reproduction of the working force via consumption and communication.

\section{The Marxist Approach and its Contestation}

In the frame of Marxist tradition, especially as it has been formulated in Marx's work "Towards a Critique of the Political Economy", the dialectics of relations of production and forces of production are considered to be a fundamental force, which contributes to the configuration of the social system as a whole, or in Marxist terms, to each socio-economic formation (Marx 1978, 115). The effort to comprehend and evaluate this dialectic in the further economic analysis, particularly within Marxism, led to the separation between those that attribute the prime role to the forces of production (means of production, objects of production, working force) and those that attribute a bigger priority to the relations of production (property relations, class relations, etc.) and furthermore to the political and ideological conflict (Plamenatz 1963, 282-283; Blackledge and Hunt 1995, 160). This division prevailed for a long period in the Marxist camp not only in theory, but also on political, cultural and other levels.

At this point it is imperative that the importance of two points is emphasized. Firstly, as we already mentioned, Marx and Engels, on one hand, define relations of production as "forms of communication" (Marx and Engels 1978a, 67). On the other, (Marx 1978), the relations of production are seen as the base, above of which is erected all what with another term could be characterized 
as "communication forms" (law, policy, art etc.) and other social institutions. It is obvious that henceforth relations of production refer mainly to an economic-social category, the class relations (or property relations) and that the "forms of communication" have been removed from the base.

In order to comprehend this contradiction, one should question whether class/property relations are distinguished from the forms of communication, where class relations determine and shape forms of communication. a) How is the existence of relations of production possible without forms of communication. b) If we remove communication from "forms of communication", then what remains of them? The answer to the first question is that it is obvious that the class relations, as all social relations, are not conceivable without the communication aspect. According to George Gerbner, communication is "social interaction through messages" or symbolic constructions (Gerbner 1970, 72). Thus, the various class relations (also including their political form) are possible only via communication and the various forms and types of communication. Actually, class relations acquire substance and are transformed (to the particular historical form that they take in each society) via the forms of communication.

Based on our previous analysis, the answer to the second question, i.e. what remains from the "forms of communication" if we remove communication altogether, is: ideas. Consequently, at a second stage or moment, classic Marxism perceives the "superstructure" as a whole of ideas, as Marx himself wrote (Marx and Engels 1975, 68), that are shaped by the material base of society, in which the institutional mechanisms of the production of ideas are also included,.

This approach has been interpreted mainly in two ways. Firstly, the Marxist approach, especially the analysis of capitalism, was seen as a theoretically erroneous or one-sided approach. This stance has been especially popular within positivism, functionalism and Weberian sociology (Alexander 1987). The importance of the mode of production has been pointed out, but has been considered to be rather one-sided. In this case, the economy has been considered as an insufficient factor for further social analysis. Marx and Engels have also pointed out that the analysis of the societal organization must be completed by communication/culture or by what in Engels' words has been called "form" of the "content", which in its turn are the economic processes. This work, according Engels, had to be carried out by the next generation of Marxists (Marx and Engels 1978b, 469).

Secondly, the classic Marxist approach (mainly in Marx's "Capital") is characterized as a theoretical imprinting of a historical reality. Marx actually describes the way in which $19^{\text {th }}$ century laissez faire capitalism operates (Russell 2006, 26-29), not capitalism in general or class societies in more general terms. In my opinion this assumption is also at the heart of the Williams' conclusion that the base-superstructure model is a bourgeois formula (Williams 1978, 75-82). Thus the analysis of further stages of capitalism should take into consideration the role of communication/culture.

So, no matter if one looks from inside or from outside at the initial Marxist position on the role of the mode of production or class relations in the organization of society, one can observe a convergence. It concerns the need to complete the role that is carried out by the "base" or more widely the mode of production, from the activities that take place in the superstructure. This conclusion, like similar developments in social theory, owes a lot to theoretical activity. However, the conclusions did not become only possible due to theory, they at the same time had to be applied in the ontological field (Horkheimer 1976, 213). Theories are social constructs and social constructions are never arbitrary, except in solipsism (Demertzis 2002, 144-175). Social constructions always organize through discourse a sum of events that are independent from individual subjects, not of the subject in general. Or they contain events that are objective as the natural or economic events (Demertzis 2002, 149-152).

The perception that the mature Marx described a specific socio-economic formation in a specific period, appears feasible at least for two reasons. Firstly, it corresponds to the more general course of his work from the abstract and general to the concrete and specific, and from the philosophical and general sociological analysis to the economic and political one. Secondly, the description of capitalism, capital, work, commodity etc. that Marx develops in "Capital", constitutes an analysis of an "ideotypical" capitalism. But it could historically be observed in the frame of liberal, laissez-faire capitalism, and particularly in Great Britain.

Any attempt to adopt this analysis in any other country or form of capitalism presupposes smaller or bigger modifications, as Engels himself underlines in his letter to Paul Ernst (Engels 1978a, 426-428). These "modifications" can be perceived either as an adjustment to different historical circumstances and/or as an adjustment to a different phase, as an adjustment to the "ideotype" of another phase in the development of capitalism. 


\section{The Genesis of Symbolic Capitalism}

Seeing the ontological foundation for the characterization or the transformation of Marxist perceptions of base and superstructure as insufficient, one should turn attention to those facts that rendered it restrictive. The great transformation, according to the terminology set out by Polanyi (Polanyi 2001), is a change in the nature of capitalism that took place at the end of the 19th century. A result of this change was the appearance of monopolies or in other words organized capitalism (Lash and Urry 1987; Sennet 2008, 27) and the reduction of competitive, free market capitalist economy and the liberal state. But to look at this from another perspective, the rise of monopoly capitalism is connected to radical changes in the process of production, especially the social organization of work (Burawoy 1979), on the one hand and the rise a large public sector on the other (Hobsbawm 1978).

The significance of this change is immense for the study of communication from the Marxist perspective. Through this change, Baudrillard for example explains the development of media and the sovereignty of the mode of communication over the mode of production in an undisputed way (Baudrillard 1990, 112). Although Baudrillard correctly locates the point of historical transformation of capitalism, I believe however that he does not correctly interpret this change. Baudrillard locates this change in the market circulation of commodities and more specifically in the relationship between producer and consumer, between the commodity and its consumption. It is true that the circulation of commodities and financial capital can exercise influence over the production process, as Engels recognizes in his letter to Conrad Schmidt. But the "decisive moment" is production (Engels 1978b, 436).

The specificity of capitalism does not lie in the circulation or production of commodities (which existed before the capitalist mode of production), but in the production of surplus value and furthermore in generalized commodity production. "Capitalist production is not merely the production of commodities, it is essentially the production of surplus-value" (Marx 1979, 520). Circulation is the moment of realization of surplus value, not the moment of its creation. The most important condition for the production of surplus value is the relationship between capital and labour, where the labour force becomes itself a commodity (Jessop 2002, 12-13. The production of surplus value, and more precisely the rate of surplus value $(\mathrm{s} / \mathrm{v})$, is the historical form and essence of the capitalist relations of production. Thus, the phenomenon of monopoly as a relationship between producers and its changes are not explained or at least not located in the organization of production. From the Marxist point of view, any change in the evolution of capitalism is first and foremost a change in the form and method of the production of surplus value rather than the form of its realization (circulation of commodities), no matter how important this is for commodity production.

We can claim that the crisis of the 1870s was a crisis of the production system of surplus value in laissez faire capitalism, which according to representatives of the Regulation School (Aglieta 1979, Lipietz 1990) is characterized by extensive production of surplus value and economic development (of an individual company or national economy as a whole). The resolution of the crisis was achieved by turning to the intensive model of organized capitalism that included the appearance of monopolies. This constituted a different production system of surplus value that led to a different way of its realization.

In the extensive model (featuring laissez faire capitalism), both production and the increase in surplus value are ensured, in Marxist terms, mainly through increase of absolute surplus value production. Firstly, this takes place through wage reductions to the limits of survival combined with the extension of working hours and so on. The labour force here appears mainly as an unskilled and unwilling muscular force whose effective engagement in the production process is ensured through economic violence (lack of means of survival). Because of this function of capitalist enterprise, the intervention of politics, morality etc in the relations between capital and labour, apart from the economic means, is very difficult. This relation was present in the laissez faire capitalism of the 19th century, or the relationships between different parts of capital or between different enterprises. Secondly, and as a result of this, the extensive model (laissez faire capitalism), the absolute increase in surplus value and economic development are obtained by multiplying the business of a sole businessman through investment earnings (based on a secular or religious Protestant spirit) creating new production units. 
Hence, laissez faire capitalism was a period of unbridled expansion of industrial capitalism that reformed the structure of the economy and fundamentally altered social relations, as well as the distribution and organization of population, in the manner that second wave societies were described by Alvin Toffler (Toffler 1982). Finally, in the extensive model, as a result of all aspects mentioned earlier, the leading role in increasing absolute surplus value, according to the terminology of Rueschmeyer, is played by the technical organization of labour (Rueschemeyer 1986), in other words the organization of machinery. The continuing revolution in technology results in the reduction of the necessary labour time and the increase of surplus labor time. To sum up, laissez faire capitalism is the macroscopic aspect of absolute surplus value production in capitalism.

In my view, within this form of the capitalist economy, social communication is to a paramount degree separated from work and vice versa, although it is subjected to the same rules as labour. The labour process is free of socially-organized communication - an end in itself, serving the needs and aspirations of its subjects. Moreover, socially organized communication is subjected to a great degree to the requirements of universal exchange in two ways. On the one hand, the social production and consumption of communication that is commercialized is characterized by the same procedures and relations between producers and businesses as well as the production of material commodities.

The producers of symbolic products have more or less the same relationship with their employer as a the factory worker (Pleios 1993, 49-50; Mosco 2009, 133). This model finds its theoretical expression in Marx's conception of the commodity. Marx considered as commodity any merchandise "whether addressed to the stomach or mind" (Marx 1979, 45), exactly because of the conditions and the means of its production, and because it is produced not to meet the needs of producers, but of consumers. On the other hand, the predominance of exchange relations is expressed through the predominance of natural language, and of written language and the press in social communication in particular.

Natural language as a semiotic system becomes the symbolic equivalent of value. It becomes the symbolic "currency" to redeem "on the show" any other representation. This is why print media become the predominant media and the content categories on the axis of information - literature become predominant (content categories) inside and outside print media (Pleios 1993, 51). In other words, in laissez faire capitalism, social communication is relatively separated from labour, but both fall under the same rules of production of surplus value on the one hand and commodity production on the other. This does not mean that all cultural production and communication are commercialized. On the contrary, the masses use largely forms and products of communication that are not commercialized. This statement is especially true for socially organized, i.e. commodified, cultural production.

However, there are limits beyond which the continuity of the extensive model and laissez faire capitalism is impossible. Classical Marxist political economy interprets the emergence of monopoly capitalism (organized capitalism) mainly as a result of the relations between different parts of capital, considering the relationship between capital and labour as stable. This means that monopoly is interpreted simply as a result of the integration of individual businesses targeting the largest company's monopoly profit. As mentioned earlier, the emergence of monopoly capitalism, as well as of liberal capitalism, should be thought of as part of production (at the micro-level) rather than as part of the market (the macro-level). More specifically, the emergence of monopolies is more related to the transformation of the organic composition of capital, the relationship between constant capital (dead labour) and living labour (the workers' labour) (Marx 1979, 627-664). But the increase of the organic composition of capital, due to the primary role of the technical organization of the labour, which Marx accepts in the long-term (Marx 1979, 627 - 664), is at the same time a process of the intensification of labour, if one has to face the declining rate of profit. In other words, the increase of the organic composition of capital is at the same time an increase of the productivity of the "total quantity of live and materialized labour production" (Richta 1976, 47). Thus, the emergence of monopoly capitalism (organized capitalism) must be associated with the increase of the relative surplus value and an increase in productivity, or otherwise the transition to a new, intensive model of development of the capitalist mode of production.

This is achieved through the transformation of the social, and especially the bureaucratic organization of labour in the production process rather than by changes in technology (Rueschmeyer, 1986; Sennett 2008, 28, Braverman 1974). "The way in which the enterprises were organized internally played the most important role" (Sennett 2008, 28). Therefore, it is no coincidence that the monopolistic organization of the economy (at the macro-level) is accompanied by forms of labour 
organization (at the micro-level), such as Taylorism, Fordism, "human relations", the Gantt system, Halsey, Rowan etc. which places emphasis on the social-organizational aspect of labour (Parker 2000; Pleios 1993, 54). In fact, the intensive model is the one that brings out this aspect of organization of labour as vital in the production process. On the contrary, the social organization of labour within the extensive model, does not constitute a problem that needs special attention. Within the extensive model the social organization of labour is a mere extension of technique - machines organize work and not vice versa.

Labour under monopoly capitalism is eventually organized into patterns that can very generally be described as "military". "The profits that markets put in jeopardy, bureaucracy sought to repair" (Sennett 2008, 28). This is especially true for models like Taylorism and Fordism. Sennett mentions that the application of a military pattern of organization to the industry, and further to the rest of society, was the form of labour organization that inspired Weber and that he kept in mind in all his work. In Sennett's words: "We owe the analysis of militarization of society [...] to Max Weber" (Sennett 2008, 28), who saw and analyzed it in his own country. Germany is regarded as the birthplace or, according to Lash and Urry, the "ideal type" (Lash and Urry 1987, 17-28) of such an industrial and social organization of capitalism. However, on the one hand, these patterns of (militarily) organized capitalism and society are characterized by a vertical and strict hierarchical organization requiring discipline, and on the other hand their effectiveness is based on the voluntary involvement of individuals.

These patterns are based on the assignment of certain tasks, which must be carried out with active participation (Sennett 2008, 30-39). They require acceptance by the workforce and its voluntary conformation to them. In such an organization of labour, the economic violence upon which liberal capitalism is based, is an insufficient incentive for the workforce to be efficient. On the contrary, if the process of production shall be effective, then the relationship between labour and capital has to be built and it was built on a consensus basis (Burawoy 1979, xii). In order to be effective in the new environment, the workforce needed to find a purpose, to adopt the purposes of the productive process as if they were its own and to seek their application and fulfillment. We could note that although Marx studied liberal capitalism, Weber looked into organized capitalism. However, they both equated capitalism in general with the form of capitalism they studied.

Therefore, to achieve the necessary level of control and voluntary participation of the workforce as an essential element of the intensive model, economic violence (hunger) and the exploitation of labour through absolute surplus value that have a divisive function do not suffice. It is necessary to integrate elements apart from the economy such as political and cultural ones to the economic culture and the production process. Such purposes could be initially established and set a political vision (such as democracy, nation, or later socialism etc) (Pleios1996).

It is a fact that in the initial period of monopoly capitalism (when also the collective form of property conceals its private character), the intensive model was developed primarily as a reorganization between different forms of capital and businesses or, to be more accurate, between the state and monopolies. By the end of the First World War, this was indeed the case. Burawoy is right (Burawoy $1979, \mathrm{xi}$ ) on this point, but only regarding the initial period of organized capitalism, particularly in countries with less liberalism and a greater presence of a romantic spirit, in which the militarization of labour and of the whole of society was for different reasons easier to achieve, as e.g. in Germany, Austria, Italy, Russia, Greece etc. However, in countries influenced more by the liberal tradition, where personal gain is the existence and purpose of the state (Hobsbawm 2008, 51-52), or in countries where the intensive model exists, this development is not sustainable or feasible in the long term.

The problem of integrating extra-economic mechanisms into the production process, which ensure the voluntary participation and discipline of workers in the military organization of labour and make possible the production of relative surplus value (Jessop 2002, 56, 58), was solved by enlarged consumption (Pleios 2001, 207-209). Adorno and Horkeheimer note that "significantly, the system of the culture industry comes from the more liberal industrial countries, and all its characteristic media, such as movies, radio, jazz, and magazines, flourish there" (Adorno and Horkheimer 2001, 79).

Enlarged consumption certainly served to offset the additional forces of labour spent in intensive production. But mostly enlarged (mass) consumption was enforcing productivity, not the other way round, as some scholars suggest (Jessop 2002, 7; Matsuyama 2002). There is no rational explanation why capitalists should increase salaries of their workers given their high productivity if at the same time the higher levels of workers' consumption couldn't increase their productivity. Productivi- 
ty does not result only from "economies of scale" (Jessop 2002, 56). Increased productivity was a necessary condition for enlarged consumption only if enlarged consumption was a necessary condition for increased productivity. But from the capitalists' point of view, profits and not workers' way of life were (and still are) the purpose. Thus from the capitalists' point of view, enlarged consumption is justified only as a productive factor.

However, enlarged consumption could be a precondition of the intensive model to the degree to which: a) extra (beyond a minimum existence) money is not saved in order to protect the business system from being accessed by new competitors, but it is spent on consumption and b) when money is spent on commodities that can develop within the labour force the notions of voluntary participation and discipline. And this was (is) possible to the extent that the workforce is no longer a mass of workers excluded from privileges, but is upgraded and according to Arendt integrated in society or to some extent subjected to the same rights that the elite enjoy (Arendt 1991).

In other words, the problem was solved by the consumption of commodities - namely commodities that have a symbolic value (Baudrillard 1990; Arendt 1959, 72-83, 108-110) beyond their use value (which aims at the simple reproduction of labour power) as well as symbolic commodities (e.g. communication products). The form that this consumption took was individual.

The enlarged consumption of commodities - symbols and symbolic commodities - allowed the workforce to become subjects. Rosalind Williams in her work pointed out the connection between mass consumption and upper classes' life style (Williams 1991, 13). Thus the consumption of such commodities became means for the elaboration of common goals and meaning among the elites and the workforce. Or, as Marglin and Bhaduri have expressed it in macroeconomic terms: "If demand is high enough, the level of capacity utilization will in turn be high enough to provide for the needs of both workers and capitalists" (Marglin and Bhaduri 1990, 153). This way the workforce could share its interests with those of the elites. Thus, the main, not necessarily the more obvious, goal of the enlarged consumption was that the labour force accepted and served the historically shaped division of labour, not the diachronic division of the extra-economic power, as Baudrillard suggests (Baudrillard 2003).

In fact, the usefulness of enlarged consumption was not to form an effective workforce in terms of functionality of an unproblematic natural force, as assumed by human capital theory (Schultz 1961) or other analyses (Lash and Urry 1987, 67-8). It was, rather, to form an effective workforce with intentions and consciousness, in symbolic terms, which manifest themselves in terms of incentives, motivation, goals, etc. Such an operation is ensured at the point when consumption occurs within the context of consumerism as an ideology (Bocock 1997). In this perspective, consumerism is not so much the personal pursuit of the use value of commodities, but of their symbolic value, which represent socially acceptable virtues and ways of life (Pleios 2001, chapter 3 ). In this sense, symbolic value differs from commodity fetishism because of its key productive function and usefulness.

On the political level, the problem was resolved with the implementation of Keynesian policies, or in other words by supplementing the system of mass production with arrangements that ensured mass consumption (Aglieta 1987; Lipietz 1990). Keynesianism is not only the origin of the explosion of the production of commodities - symbols, but also of the symbolic commodities of mass culture. However, this is not the main cause, but the result of the shift to intensive production, the production of surplus value, and the extended model of development. The economic cost of wide consumption is not an expense as it may seem, but an investment (the rate of labour force), without which intensive production and high business profit are impossible.

Thus, the result and precondition of intensive production is the consumption of commodities symbols (and symbolic commodities) and vice versa. Enlarged (mass) consumption enforces productivity, not the opposite as Matsuyama suggests (Matsuyama 2002). Mass consumption aims to produce some "properties" of the labour force, and thus some factors that are necessary for mass production. In this sense enlarged consumption becomes a force of production. Its role is not limited to the sphere of circulation of symbolic commodities (directly) or/and commodity-symbols (indirectly). Besides, in many countries, the objects for enlarged consumption are being offered in natural, non-commodity form, including for example television, education or other media and cultural products (Allen 1992; Mosco 2009, 134).

This change is not only the cornerstone for the development of mass communication in general, but of visual communication as well. These visual media offer in a concrete manner the symbolic value of commodities and the notion of lifestyle that surrounds them. They offer the image of commodities as an essential precondition for the circulation of the commodity itself and also of the la- 
bourforce as a commodity. In other words, the circulation of the commodity's image becomes crucial for the circulation of the commodity itself (Adorno and Horkheimr 2001; Pleios 1993, chapter 2; 2001, chapter 3), not the opposite (Debord 1986). This shows the crucial role of culture in the capitalist mode of production and vice versa. But the enriched and costly circulation (and consumption) is possible to the extent that they can stimulate a higher productivity, which covers the cost of circulation (and consumption) and leads further to the rise of surplus value and economic growth. Thus the real scope and outcome of the enlarged consumption and circulation is the rise of surplus value (Pleios 2001, chapter 3; 1996) and not its sharing.

However, in this way, mass communication is dynamically evolving as a mechanism that encourages and implements mass cultural consumption and provides the conditions for the production of (relative) surplus value and intensive production. In this sense, mass culture and moreover commercialized communication cease to belong to the realm of the superstructure. It becomes a "basic superstructure" in the same way that it constitutes a "superstructure base". Or, in other words "things become media and media becomes things" (Lash and Lury 2007, 4).

From this viewpoint, capitalism is changing significantly and is becoming a "symbolic capitalism". It is becoming a capitalism that produces and consumes commodities - symbols (and the actual labourforce is no longer a mere commodity and becomes a broader symbolic - cultural identity). Hence, in symbolic capitalism the symbolic-informational processes are embodied organically both in production (and the production of surplus value) and in the consumption of commodities as integral elements of the economic process (Webster 1995; Castells 1996, chapter 4; Fuchs 2010b). In this way, communication is integrated again into labour but now with an instrumental logic and labour is integrated organically into communication, and into the process of the production of cultural products (cultural industries). But this integration is achieved in a way that connects these procedures organically as contributors to the system function as a whole. On the macro-level, the combination of "economic and extra-economic institutions and practices" becomes a key structural feature of symbolic capitalism (Jessop and Sum 2006, 1).

From this perspective, what Cultural Political Economy stresses (Jessop 1990), is rather a historical product of capitalism's evolution. In this process, symbolic capitalism appears in many national, cultural and other forms because communication and culture are not yet an epiphenomenon or simply a superstructure. On the contrary, they become a structural element of relations of production and of the mode of production. However, these different forms of symbolic capitalism do not constitute national or cultural exceptions compared to an "ideal" symbolic capitalism. They are rather specific forms of a more generalized phenomenon - symbolic capitalism. The relation between symbolic capitalism in general and the specific national or other symbolic capitalisms (e.g. Western European or American or Mediterranean capitalism) is the relation between the general and the specific. This problem is of great importance in theorizing symbolic capitalism, but its analysis lies far beyond the purposes of the present paper. Symbolic capitalism appears at the interception of two changes. First, the shift to or the establishment of relative surplus value within the relations of production (the intensive model of capitalist production) and second the introduction of enlarged consumption regulations that sustain the intensive model.

Furthermore, the diversity of symbolic capitalism depends mostly on three factors. Firstly, it depends on the type of welfare state that follows a specific form of enlarged consumption. Esping Andersen's study of welfare regimes concludes that there have been three (later four) types of welfare state: Liberal (e.g. USA), Corporatist- Statist (e.g. Germany), Social Democratic (e.g. Scandinavian countries) and Mediterranean (e.g. Greece) (Esping-Andersen 1990, 1999).

Following this typology, we could say that there have been four types of enlarged consumption.

a) A type of enlarged consumption based on limited state intervention on the one hand and individual distribution on the other. In that case, the means for enlarged consumption, a minimum social wage, are given mostly in the form of money to the working individual in order to buy education and healthcare services, mass media products etc (e.g. USA).

b) A type of enlarged consumption, based also on market relations on the one hand but on collective distribution on the other - families, professional groups etc (e.g. Germany). Within that model, local, religious, or other organizations provide non-commodity services (e.g. childcare services) to disadvantaged social groups.

c) A type of welfare state that is based upon state intervention and individualism. The means for enlarged consumption are given to the working individual not only in commodity form (wage), but also in non-commodity or natural form - direct access to education and health services, mass media products etc (e.g. Scandinavian countries). 
d) A type of welfare state that is based also upon state intervention, but where the means for enlarged consumption, in commodity as well as in non-commodity form, are addressed to the family and professional or social groups etc (e.g. Greece).

Secondly, the variety of symbolic capitalism depends on the extent and form of traditional culture that prevails in society. More precisely, it depends on the functions of traditions in modern societies. Thompson (1995) supports the idea that traditions carry the potential for the following functions: interpretation, legitimation, normativity, and identity. According to Thompson, in modern societies only two of them, namely interpretation and identity functions, are still active. $\mathrm{n}$ my opinion, this is so in typical Western democracies. On the contrary, in authoritarian regimes tradition often had also less or more normative and legitimatory functions supported by state power.

This was the case in Greece for a long period of time. In this case, enlarged consumption is encapsulated in traditional, cultural nationalist or even religious practices and discourses (Tsoukalas 1983). In my opinion, the wider the presence of traditions (especially its normative and legitimatory functions) in the cultural system, the more extra-econonomic (e.g. political) scopes are being served by enlarged consumption. That may also mean a non-effective or non-rational interrelation between the intensive model on the one hand and the enlarged consumption on the other (Charalambis 1983). This results in a higher autonomy of enlarged consumption from the intensive model.

Thirdly, the variety of symbolic capitalism depends also on political culture and the political system in a given society. However, as I mentioned earlier, this needs more systematic elaboration.

\section{The Two Eras of Symbolic Capitalism}

Although we generally have not left behind us the era that initiated the crisis of 1870 and particularly the end of WWI, the period of symbolic capitalism does not have a homogeneous character. We can distinguish two distinct sub-periods. The first period is strongly connected to mass production, mass consumption and Fordism, and very generally it is the first/initial period of symbolic capitalism, which is organically linked to heavy industrial machinery on the hand and the hierarchical, one-dimensional old media on the other. The second period was initiated by the economic and cultural crisis of the 1960s-70s and the new phase of globalization that has been characterized by diversified production and consumption and is inextricably linked to information technologies and "new media" (Davis 1988, Castells 1991; Mosco 2009, 15).

\subsection{The Initial, Symbolic (or Organized) Capitalism}

The first era of symbolic capitalism, the one that from another perspective is the socio-economic core of a mature (vs. early) modernity, is actually a transition period between industrial capitalism of early modernity and post-industrial capitalism of late modernity. As mentioned earlier, this first era was shaped by mass production and mass consumption. More precisely, it was shaped by Fordism as a form of work organization, and led to mass (intensive) production and enlarged consumption (monopoly regulation of labour relations) (Lipietz, 1990).

The model of mass production was not invented during by Fordism, but had already existed before, in early industrial capitalism (Chandler 1994, 1-14). In the words of Daniel Bell: "Almost all the major industries we still have - steel, electric power, telegraph, telephone, automobiles, aviation were $19^{\text {th }}$ century industries" (Bell 1999, 20). What Fordism did was that it directed the intensive pattern and extended it into any possible direction. The really new element was not mass production, but enlarged consumption (Baudrillard 1990, 112), characterized by commodities that were mass-produced. This development took place, as pointed out by representatives of the Frankfurt School, by transferring the model of massive industrial production to symbolic commodities (cultural industries) (Horkheimer and Adorno 1986). But, as we shall see below, the enlarged consumption of commodities - symbols or even more symbolic commodities - was the main factor of depletion of mature and any previous capitalism.

Enlarged consumption was a process of appropriation of all these symbolic values that were unthinkable without the mechanisms of promotion (e.g. advertising) and mass culture (Wernick 1991, Ewen 2001, Lash and Lury 2007). Through such mechanisms, the creation of an illusory social mobility within the labourforce and an identification with the upper classes were enabled. In other words, the enlarged consumption became the basis of what Sennet described as "social capital- 
ism" (Sennett 2008, 35-44). This fact resulted in achieving social cohesion, social peace, political stability (Breed 1958), as well as the planned systemic organization of society at the national level, which strengthened the nation state as a whole organization of society, and nationalism as ideology.

Consequently, the new development was really the industrial mass production of socially organized communication (Horkheimer and Adorno 1986). This was a key factor in intensive production. I don't think that Burawoy (1979) is right when he separates the consensus at the work place from the consensus achieved through media and enlarged consumption. In my opinion they are interconnected. The cultural industry includes the industrial mass production of many and different commodities or symbolic products, products that are organized by various symbolic systems. However, for reasons that I cannot elaborate here in details, for the most important reason for the emergence and reproduction of consumerism was the moving image (Pleios 2001, chapter 4).

It should not be regarded as a coincidence that the period of the emergence of organized capitalism was not only the period of the flourishing of enlarged consumption and display devices, but also the period of the emergence and dominance of cinema and later of television in social communication. The moving image can be defined as a changing set of visual images (according to Arnheim the image represents an object to a higher degree of abstraction) (Arnheim 1969, 135152) resulting in a specific performance of an abstract representation of symbolic importance.

In other words, this created at the level of communication and especially of text, what was for the simple worker organized capitalism at the level of production and especially at the level of enlarged consumption, i.e. it offered its prototype and meaning (Debord 1986; Ewen 1999; Pleios 2001, chapter 3 ). In this sense not only television but also any iconistic medium can be a source of lifestyle patterns in consumer capitalism. Therefore, both cultural consumption in general and even more the consumption of moving images and enlarged consumption were interdependent with Fordist mass production (Benjamin 1968). If intensive production was the hallmark of organized capitalism, then the hallmark in public communication was the dominance of the moving image. Consumption commodities - symbols - constituted the core in the fields of society and culture.

I should note here that the moving image does not relate to the specific forms of audiovisual media such as cinema or TV, but is an attribute of many representational systems and particularly audiovisual ones. In fact, cinema, television, video and digital modern media (such as computers or the internet), are different and successive forms of the moving image that are in line with different forms of symbolic capitalism (Pleios 1993). Therefore, from a sociological and cultural point of view. they should not be compared only among themselves but mainly in relation to their respective socio-economic and cultural conditions in which they occur and which they serve and are served by them. In this sense, the enlarged consumption (of commodities - symbols) and cultural industries, are indissolubly linked to the intensive, organized capitalism or in other words to the first period of symbolic capitalism. The enlarged consumption and cultural industries allow for intensive production and its dynamics, as well as profitability and financial development of countries and businesses.

If one looks at this the other way round, the cost of enlarged consumption and cultural industry (especially that of heavy cultural industry such as the visual one) is covered by the high productivity model (Matsuyama 2002). This relationship is certainly possible under the condition that it occurs in a strictly national systemic organization. Looking into the matter from the Marxist perspective, we come to the conclusion that the "forms of communication" are no longer part of the superstructure, but a condition that ensures the process of production and the production of surplus value. They constitute a factor of production. In other words, although capitalism is identical with the removal of any extra-economic relations regarding the shaping of economic inequalities (Wood 1997), in its evolution, the extra-economic relations are organically embedded in economic ones, especially in relations of production and the production of surplus value.

But the question that is most interesting from the perspective of future developments is the one about the boundaries of the system and the reasons which rendered it historically obsolete. From the point that this issue is approached, there are three conditions that make the system of intensive organized capitalism viable: a) mass consumption, which ensures mass production and therefore the functioning of the enlarged consumption as an engine for intensive development, b) the amortization of the costs of enlarged consumption through the contribution of enlarged consumption to increased productivity and surplus value, and therefore, the maintenance of class stratification, c) the national and systemic organization of society based on this status. 
These three conditions were shaken, which resulted in the beginning of the degradation of organized intensive capitalism and the welfare state (Lash and Urry 1987; Lipietz 1990). Differentiated consumer demand and flexible production became a key industrial tendency in the late 60s and onward (Jameson 1984, Harvey 1989, Castells 1991; Mosco 2009, 15). The rebellions of 1968 seem to be uprisings against mass consumption and a turn to diversified, fragmented and/or individualized consumption of commodities - symbols and symbolic commodities (Perniola 1991, 30 40). Representatives of the Regulation School showed that the enlarged consumption following an increasing trend could further contribute to economic development and profitability, leading to an inverse relationship, while the reduction of class differences that was caused by a reduction in profitability led the ruling classes to react with cuts in welfare policies and the flow of capital abroad in search of cheaper inputs (Lipietz 1990; Vergopoulos 1999). Therefore, the national organization of capitalism changed due to the contemporary phase of globalization (Sassen 2009, 113-124).

Although these three factors are equally important, very often authors argue that one or two of them were catalytic in the overthrow of the system of mass production - enlarged (cultural) consumption with particular emphasis placed on globalization (Sassen 2009, Sennet, 2008). However, we must concentrate our attention to the core of the system on the micro-level. As mentioned earli$\mathrm{er}$, this is the ability of consumption, through its symbolic functions, to contribute to the discipline of employees, organization and the logic of production, as well as to the increase of productivity and profitability. Therefore, the dismantling of the system should be sought in changes occurring on a symbolic-communicative level and its social and economic functions.

The enlarged consumption of commodity-symbols and of symbolic commodities can be put in a double sense, as Hall (1980) has shown for the second case, but above all it is a symboliccommunicative process, as the appropriation of symbolic value is more important in social terms. Production and the exchange and consumption of symbolic commodities in particular as an economic process cannot be explained without first understanding its symbolic-communicative dimension (Hall 1980). As a result, we must first explain the function of symbolic commodities as text in the frame of social conditions. This function was to provide an illusional individual social mobility, individual freedom from social constraints and individualization in general. Besides, especially in visual production as shown by Hall (Hall 1980), the basic mechanism of interpretation are the connotation and personal experiences and aspirations. Therefore, from this point onwards, mass consumption cannot satisfy the functions for which it was established. This fact is a straight questioning of its foundations, i.e. of mass production. On the other hand, the continuous expansion of the enlarged consumption, that is its nuclear element with the assistance of social demands, have contributed so that it cannot contribute to growth or cause a reduction in profitability and economic development (Lipietz 1990).

\subsection{Deep Symbolic (or Disorganized) Capitalism}

The crisis of organized, intensive (and symbolic) capitalism emerged as the imbalance between the efficiency of the production system on the one hand and the cost of enlarged consumption on the other. In other words, the enlarged consumption could contribute to an increased productivity (growth) of the economic system. While the cost of enlarged consumption remained stable, or (mainly) increased, the levels of productivity remained stable or increased.

This was expressed as a reduction in profits ("profit squeeze") (Marglin and Bhaduri 1990), which needed to be addressed in order to ensure the existence of class rule. As shown by the analyses of the representatives of the Regulation School, this crisis was actually a crisis of "underproductivity" or the decrease of the rate of productivity in the late '60s and '70s (Lipietz 1990; Cook 1990, 79-84). While the working class enjoyed the benefits of enlarged consumption, this did not lead to the purpose, for which it was established (to increase productivity and profitability of intensive production). It became a social and cultural process detached from its economic base in the given class structure.

This crisis was initially treated in two ways that, however, did not reach the root of the problem: a) the flow of businesses abroad, where they could find cheaper labour (Elam 2000, 64-65) and/or b) the reduction of enlarged consumption (Lipietz 1990; Pond 1989). Nevertheless, the radical treatment of the problem required the activation of the "interest" of employees so that their work could contribute to a productivity and profitability increase, as it was the case with the establishment of enlarged consumption. Thus, the idea was that the logic of symbolic capitalism should be maintained but the means by which its financial results are achieved should change. In other 
words, the production system should be reconstructed in the direction that the logic of consumption had changed (commodity-symbols and symbolic commodities) as well as social action had as a whole. Key elements of this change were the differentiation-individualization, active interaction of the public and the collapse of the one-way hierarchical action, the activation of the symbolic, the cultural capital of the public etc (Lash and Urry 1994).

The necessary changes in the production system that faced the crisis of "under-productivity" were completed by two simultaneous and interlinked transformations: firstly the technical organization of labour (Robins and Webster 1988; Toffler 1982; Webster 1995, chapter 1) and secondly the social organization of labour (Lipietz 1994, Mouriki 1994). The introduction of digital technologies of automation, basically communication and information technologies (Richta 1976, Castells 1991; Mosco 2009, 15), has enabled the diversification of production in order to meet the diverse needs of consumption (Davis 2001). That had already been created through the "game" of communication in the field of enlarged consumption, which besides was the key factor for the maintenance and expansion of this consumption (Bauman 2005, 16-33; Pleios 2001, chapter 3).

It should be underlined that beyond the sphere of production, the emergence of "new media" in the area of cultural consumption, such as the Internet, was the result not only of technological developments. It was mostly the result of the circumstance that these technological developments provided answers to the democratization demand and the individualization of the communication process. But that demand had already developed in the period of the "old media". "Old media" were long before the emergence of the "new media» the centre of theoretical, social and political criticism due to their centralized and one-dimensional nature (Baudrillard 1986, Manovich 2001).

This was perfectly logical as the logic of consumption of symbolic commodities and commoditysymbols evolved in the exact opposite direction from that of the "old media". The logic of cultural consumption had the characteristics of individual choice and the ability of participation, active personal involvement, negotiation of meaning. We should also note that the exact same logic of democratization and participation that is visible in cultural consumption (Jameson 1991), was also the case in the area of commodity-symbols' consumption (Brown 1992) and that democratization is an inherent and permanent process within enlarged consumption (McCracken 1988).

As far as the social organization of labour is concerned, the transformations made in order to attract "the interest" of workers were applied through the introduction of the so-called post-Fordist forms of work organization (Lipietz 1994, Mouriki 1994). In contrast to Fordism and its "single logic", post-Fordism does not consist of a single model of organization, but includes many different and complementary settings (Hirst and Zeitlin 1991). As Amin underlines: "The relationship between the ideal-type of dominant form of Fordism has also been questioned, with critics arguing that recognition of national diversity undermines the notion of a single, dominant Fordist logic" (Amin 1994, 11). Coriat also recognizes that the world wide spread of Fordism was the expansion of a single Fordist model - that of the American methods of mass production (Coriat 1997, 242). The multiple logic of post-Fordism makes perfect sense if one considers that the purpose is to cause the active participation of workers, characterized by different ways of thinking and living, not only on a global, but also on a national and local scale. On the macro-level it depends on "whether capital, labour, or the state has the most influence over the process of restructuring" (Lash and Baggueley 1988).

Despite their diversity, the post-Fordist settings are based on a new type of labour motivation, which can be described as "production initiative" as opposed to "production discipline", which is the case in the Fordist organization of labour (Pleios, 1996). The "production discipline" required the voluntarily discipline of employees concerning the logic and purpose of production, as well as the pace in order to satisfy the common interests of workers and employers, business and national economy, economy and state. Meeting the specific individual goals, lifestyles, etc. was a case of free time and enlarged consumption, which depended upon the efficiency of the production process.

On the contrary, "production initiative" combines the participation of the employees with a real interest in achieving personal goals, as if the success of the company, the overall process within the business, was a personal matter of the employee. "Production initiative" is characterized by "loyalty to the company" and a "more committed workforce" (Hickox and Moore 1992, 109). In this case, not only material economic objectives, but also the exercise o control and authority, the projection of particular views and taste, in a nutshell the complete manifestation of the personality of the individual, lies therein. Therefore, particular features of post-Fordism are to create a horizontal hierarchy, to transfer administrative responsibilities to the workforce, and also personal involve- 
ment, horizontal cooperation, participation, the effective use of educational, symbolic and cultural capital, the identification of the worker not only as producer, but also as a citizen and consumer (Lipietz 1997; Mouriki 1994; Sennett 2008).

The introduction of horizontal hierarchy, combined with other elements as well as the responsibility involved that is required due to the use of new technologies, lead to the false assumption of an elimination of class and other social differences in the production process. Thus, functions applied by enlarged consumption are now undertaken by the production process through a set of settings that are regarded as post-Fordist. This is the first, and in a macro-perspective, perhaps the less obvious side of the change. The other one and more obvious change is constituted by the strengthening of the power and functions of the central units of a (worldwide) production system. Sennet remarks that "One of the consequences of the information revolution has thus been to replace modulation and interpretation of commands by a new kind of centralization" (Sennett 2008, 39). Sassen also points out that the functions of the central units of such a (global) system, especially in the area of finances and the new economy, are being strengthened (Sassen 2009, 99100). Hence, these two sides of the new organization of labour taken together lead not to a military, but to a "gang" or "guerilla" like structure, as one can see for example in the advertising industry (Arvidsson 2007). It is similar to the military structure of organized capitalism but without any civic, political, ideological or other commitment, value system or restrictions, beyond effectivity and success. Sennett describes this new form of social organization of labour as "MP3 organization", and it differs from the pyramidal, hierarchical form of organized symbolic capitalism (Sennett 2008, 6588). This form of labour can respond to the new technological organization (digital automation technologies) and to the needs of diverse, flexible and changing production and vice versa (Amin 1994, 14-15; Davis 2001).

Thus, a major difference of developed (deep) symbolic capitalism in comparison to both liberal and initial symbolic (or organized) capitalism is the simultaneous change in both the technological and social organization of labour. Unlike in the liberal capitalism of the 19th century when the technological organization of labour plays a key role, and the initial symbolic capitalism where the social organization of labour takes a decisive role in the deep symbolic (or disorganized) capitalism, both technology and social (re-)organization of labour now have the same importance. Technological change comes hand in hand with a new form of social organization of labour and vice versa based on the "production initiative". It is impossible to separate in technologies (of production) the technical aspects from communication aspects -social aspect and vice versa. It is a combination of technicality and communication forms. Thus, a key aspect of the work organization of labour, the organization of power relations in the production process, comes to overcome the inequality that results from property relations. That was covered symbolically by enlarged consumption, ensuring the discipline and active participation of the workforce, the objectives and rationale of intensive production.

The points that can be analyzed are numerous. Among them, two are of particular importance in our analysis. First of all, the changes made in the area of labour and the production process, at least concerning the structure and their rationale, from a temporal, spatial and social point of view derive from the field of enlarged consumption both of commodity-symbols and symbolic commodities, which were developed thanks to a variety of communication "'games". In other words, it is rather post-Fordism that comes from postmodernism than the opposite, or at least in Gartman's view, postmodernism "dialectically influenced this economic change" (Gartman 1998, 119). Thus, it seems that changes in the mode of production are imported and incorporated into production to a great extent from the area of enlarged consumption. From a Marxist perspective, in the "new capitalism" not only the role of communication (and of the "superstructure" as a whole) stays intact, but it also becomes more vital as a factor of production, though in a new social form/structure. The change in communication forms serves as a guide and supplement for changes in production relations and the mode of production. Therefore, not only does it not get diminished, but it also becomes even more organic as far as the character of the new capitalism as symbolic capitalism is concerned.

Moreover, the fact that patterns of change in production come more or less from the area of (enlarged) consumption and socially organized mediated communication, implies that a part of the enlarged consumption has become superfluous. Its functions are undertaken by the changes in production and particularly in social organization of labour or, at least become more "rational" from an economic point of view (including the privatization and individualization of consumption) (Hamnet 1989). This does not only reduce the costs of consumption and therefore increases profitability 
in production, but also achieves a more solid consensus, an objective identification between workers and employers, and effective stability. This is valid especially at the micro-level, without needing to have long-term arrangements on the level of public policies that the welfare state required (monopolistic regulation of labour) (Jessop 1994, Loader and Burrows 1994). Secondly, the (digital) technology used in the automation of production is structurally and functionally similar to that used in consumption (Sennett 2008; Barrett and Davidson 2008; Fuchs 2010b). This stands in contrast to what was happening in symbolic capitalism, where production technology differs significantly from the technology of enlarged consumer activity of symbolic products or commodity-symbols (Burawoy 1979). This has many side effects.

First and foremost, the ability to use technology and the culture of new technology acquired in the area of cultural consumption is a qualification needed to operate in the area of work (labour or education) and vice versa (Green, Reid and Bigum 1998, 22; Gualerzi 2010, 147). Secondly, among others, it has resulted in the relative decline of significance of formal qualifications compared to the merits (or the qualifications acquired at the workplace) of the labour market and the emergence of a new egalitarianism that eliminates the differences between different hierarchical levels of knowledge and qualifications. As Thursfield points out: "technological innovations may, for example, deskill task but not the worker, although worker's skills may be devalued as a result of this process. In addition, although a worker may not possess formal qualifications, he or she may be high skilled in the task requirements of their particular occupation" (Thursfield 2003, 47). What formal education provides to the workforce in order to be effective in the post-Fordist work organization, is a working ethos and citizenship rather than a set of work skills and knowledge (Hickox and Moore 1992, 108-110). This means that the overall skills that are necessary at the workplace are a matter of socialization in a broad sense (Pleios, 2004). This is shown particularly in the "new media" and cultural consumption and public communication, especially on the Internet. As Poulet has shown regarding the interaction between press and the Internet, in the latter knowledge is equated with the opinion of amateurs on various issues and in general there is a widening egalitarianism, which overrides any established hierarchies of formal knowledge (Poulet 2009, 175-178). Successful is not the one who is good in one field, but the one that is becoming popular in the public. This also occurs in the production process, but through a set of complex interactions in a postFordist business (Sennett 2009; Terranova 2004, 20-27).

Thirdly, the use of new technologies in production, especially when coupled with strengthening functions of the central units of a system, eliminate the autonomy of individual sectors and their placement in a direct decision-making center, at the end of complex interactions (Sennet 2008; Sassen 2009). The same can be observed in the field of communication, which means that the MP3 structure becomes a more general structure of social action. Overcoming the independence of functional units, is something that characterizes texts as well, particularly in "new media". Differences of content categories tend to become assimilated to a great extent (Hill 2007). Almost all types of content fall within a new paradigm, that of "pleasant information" and not just information, as claimed by theories of the information society. "Information" is rather a quantitative-technical dimension of the content (Webster 2005). In qualitative terms, texts can coexist and can be shared because they have a common qualitative ground. They inform and at the same time they entertain. In other words, they are organized according to infotainment patterns (Thussu 2007) and this tends to eliminate the large differences between different types of content categories and the various texts (Pleios 2011, chapter 2). The differences in the content categories are more quantitative and technical rather than textual.

Fourth, these processes in the sphere of production unfold mostly on a symbolic and functional level and less on an economic and structural-divisive one, as it was the case in initial symbolic capitalism. The differences in social class and economic level as well as the differences in the "order of discourse" (Fairclough 1995, 78) on the text level are realities that are significantly curtailed. Thus, the emergence of MP3 capitalism contributes to an even greater convergence and continuous dynamic permutation of production and consumption, work and communication, economy and culture (Toffler 1982; Fuchs 2010a). The difference is that Toffler focused on the functional aspect of the phenomenon rather than on the fact that it is based on social inequality and class relations that exist in the production process. The convergence and swapping of communication and production can take many forms.

Fuchs (2010a) indicates that the free work of the Internet user for entertainment purposes is utilized for product marketing, i.e. the entertainment of the user becomes work for profit. Despite the importance of other aspects of this convergence, its main dimension is surplus value production, 
i.e. (digital) communication enhances the productivity of labour force and thus reduces the time required for reproduction, not only in the field of the realization of surplus value, i.e. trade. Besides, "new media" and especially the Internet have been created according to the model of the telephone that in turn derived from business needs and reflects their organization and relationships (Garnham 2003).

However, from this approach, the distinction between the base and the superstructure disappears even further, as well as the distinction between work and communication, which allows focusing on the functional aspect of the phenomenon. Therefore, the use of "new media", which are at the same time means of production and means of communication, inevitably links the logic of labour to the logic of entertainment, the logic of production to the logic of consumption (Toffler 1982, Fuchs 2010a). A supporting role in this is played by the technical and institutional capacity of free and working time, leisure and work, workplace and leisure space. As a result, work is treated as a process of pursuing individual goals and personal pleasure and personal fulfillment process as a job, as an activity to produce useful causes for the subject. In my opinion this constitutes a typical distancing from the literal meaning of economic Marxism, but on the other hand it is a rapprochement of sociological and philosophical Marxism.

\section{Conclusion}

From the Marxist perspective, the analysis of social process acquires a practical importance to the degree to which it examines and participates in the process of social change, as it was claimed by Marx himself in the famous 11th Feuerbach thesis. Social science does not exist for its own sake (to explain the world), but for the change and progress of society. This way, this social analysis fulfills its social utility and functional existence in a society, in which there is a division of labour.

The question that arises is whether social change is a reality in deep symbolic capitalism. According to the analysis presented above, the development of relations of production within the capitalist mode of production, leads to revisions and even false democratization (at least partially) of the relations of production, power relations, and the management of the production process. Horizontal hierarchies, labour force participation, the transfer of administrative functions to the labour force etc. are signs of this change. Moreover, and most importantly, this change is organically associated with a certain form of communication, which is consistent with the so-called "information society" (Webster 1995; Castells 1996, Poster 1990). In deep symbolic capitalism, a core direction of change is towards power relations and production management and it is true that this side of deep symbolic capitalism has been neglected in the post-Fordist approach (Vallas 1999; Kennett 2003). Instead, in initial symbolic capitalism, the change was one of relations of consumption firstly and secondly of power relations. This reflects the strong relationship of initial symbolic capitalism with the past, with liberal capitalism. However, the change in the relations of production in deep symbolic capitalism appears as a continuation of changes in initial symbolic capitalism.

The social relations of power and management in the production process are perhaps the most primordial and long established relations of class and social inequality (Mann 1986), structured also (and mostly) symbolically and not only by economic means (Mouzelis 2008, 10). Perhaps that's why the changes in power relations seem to be more important in deep symbolic capitalism compared to initial symbolic capitalism. It is all about power relations and other forms of production relations are the means. It seems that the development of the capitalist mode of production and especially of its relations of production, due to their symbolization, leads to the point, where power relations become more or at least equally important compared to other forms of relations of production, despite the fact that this happens in order to hide the latter. Perhaps this circumstance fueled Baudrillard's postmodern criticism (as well as poststructuralism's approach), who recognized that relations of production (and consumption) serve power relations and not vice versa (Baudrillard 1990). From this perspective, we should consider postmodern social theory more as a distorted reflection of the reality of deep symbolic capitalism than as a set of diachronic truth claims.

Thus, it appears that relations of production (of deep symbolic capitalism) are associated organically with "forms of communication" of the information society. This change, as it happened earlier on with enlarged consumption, serves both the concealment of class inequality and capital accumulation/the production of more surplus value. But what is most important is that the "forms of communication" are not considered as passive anymore when compared to relations of production.

In other words, communication in deep symbolic capitalism is becoming the guide of conservation or change of the mode of production and especially of its relations of production. Certainly 
something similar happened in the past with the democratization of consumption. However, this situation differs significantly in that this interaction is not regulated mostly at the macro- or midterm level, i.e. that of a whole national economy, but largely takes place at the micro-level of an enterprise or a local economy and, as a result, it is not necessary to keep up the regulations at the enterprise level with the regulations at the national level - in fact the national regulations are significantly cut down.

This conclusion leads us to a fundamental issue. The process of social change does no longer necessary depends mainly on the developments at the macro-level. In other words, changes in "relations of production" can be caused by appropriate changes in communication. It is not necessary to require regulations primarily at the level of a national society or transnational ones (or transnational formations). From the standpoint of classical Marxism, this has enormous significance. Firstly, social change (including change of class relations) can be achieved through the kind and forms of communication developed in deep symbolic capitalism and secondly it can be performed at the level of individual economic structures or businesses, changes that explain the historical basis of modern relativism. In other words, it is no longer essential to seize power in order for someone to be able to change the world, but as argued by John Halloway this can be done without seizing power (Holloway 2006, 340), changing the world from below, changing the world in parts. Holloway notes that today social relations can change the capitalist relations of production. The error of Holloway, in my opinion, is that he neglects the power of technology and especially the power of communication in social change.

Social change can partly be achieved in individual parts of the economic system, especially if one considers this system not as national or global, i.e. in the context of globalization. This does not mean that regulations at the macro-level are not necessary. Social change at the workplace is impossible without its socio-political equivalent and vice versa. What links these two spheres is the tendency towards grassroots democracy. If deep symbolic capitalism and information technologies go hand in hand with horizontal hierarchies at the work place, then democratization in the economic sphere is impossible without grassroots democracy in the political sphere - and vice versa. In my opinion, the use of "new media", such as blogs, social media etc, in protests and symbolic politics is needed in order to achieve grassroots democracy, especially since "military" organized economies and hierarchical party democracies have failed. This could explain to some degree the 'indignados" movements (all based on "new media') in very different countries, such as Egypt, Algeria, Spain, Greece, or the USA.

Greece has a failed, state-centred, economic system (Sakellaropoulos 1992; Kazakos 2001). At the same time, it has a failed (and corrupt) centralized party democracy (Lyrintzis, Nikolakopoulos and Sotiropoulos 1996). Thus, it can be explained, at least to some extent, why during the last two years (2010-2012), the "new media" have played a crucial role in the delegitimization of the political system as well as in the emergence of new grassroots political organizations and mobilizations. These movements would be unthinkable without the "new media" and new kinds of content (Labrakou 2011). This movement in Greece has already been called "The Facebook May 1968". But the problem of social change remains unsolved until one can achieve grassroots regulations in the political sphere as well as in the relations of production.

Grassroots democracy in politics as well as in economy cannot be achieved only by use of "new media". In my opinion "new media' no matter where they are used, in politics or in the production process, are today still based on the "spectacle'. Image/spectacle, though in a different manner, still play a key structural role in "new media" as well as in "old media" and enlarged consumption. However, in the process of social change, social scientists are no longer the generals, but the engineers of this change. In the age of information technologies, the functional and the revolutionary side of the social scientist converge to a new indivisible whole.

\section{References}

Adorno, Theodor and Horkheimer, Max. 1987. Sociology. Essays. Athens: Kritiki (in Greek).

Adorno, Theodor and Horkheimer, Max. 2001. The Culture Industry: Enlightenment as Mass Deception. In Media and Cultural Studies. Keyworks, edited by Meenakshi Durham and Douglas Kellner, 71 - 101. Oxford: Blackwell.

Aglietta Michael. 1979. A Theory of Capitalist Regulation: The US Experience. London: Verso.

Alexander, Jeffrey. 1987. Sociological Theory Since World War II. New York: Columbia University Press.

Allen, Robert. 1992. Audience-Oriented Criticism and Television. In Channels of Discourse, Reassembled: Television and Contemporary Criticism, edited by Robert Allen, 101 - 137. London: Routledge. 
Althusser, Louis. 1990. Positions. Athens: Themelio (in Greek).

Amin, Ash. 1994. Post-Fordism. Models, Fantasies and Models of Transition. In Post-Fordism: aAReader, edited by Ash Amin, 1 - 39. Massachusetts: Blackwell.

Arendt, Hannah. 1959. The Human Condition. A Study of the Central Dilemmas Facing Modern Man. Garden City, New York. Anchor Books.

Arendt, Hannah. 1991. Society and Culture. In The Media Culture, edited by Kostas Livieratos and Takis Fragoulis, $121-$ 126. Athens: Alexandria (in Greek).

Arvidsson, Adam. 2007. Creative Class or Administrative Class? ephemera. theory \& politics in organization 7 (1): 8-23 .

Barrett, Michael and Elizabeth Davidson. 2008. Exploring the Diversity of Service Worlds in the Service Economy. In Information Technology in the Service Economy: Challenges and Possibilities for the $21^{\text {st }}$ Century, edited by Michael Barrett, Elizabeth Davidson, Catherine Middleton and Janice DeGross, $1-12.2^{\text {nd }}$ edition. New York: Springer.

Baudrillard, Jean. 1986. Requiem for the Mass Media. Athens: Eleftheros Typos (in Greek).

Baudrillard, Jean. 1990. The Mirror of Production. Athens: Alexandria (in Greek).

Baudrillard, Jean. 2003. The Consumer Society. Myths and Structures. London: Sage.

Bauman, Zygmunt. 2005. Work, Consumerism and the Poor. Berkshire: McGraw Hill.

Bell, Daniel. 1999. The Coming of Post-Industrial Society. A Venture in Social Forecasting. New York: Basic Books.

Benjamin, Walter. 1968. The Work of Art in the Age of Mechanical Reproduction. In Illuminations, edited by Walter Benjamin and Hannah Arendt, 219-253. New York: Harcourt, Brace and World.

Blackledge, David and Hunt Barry. 1995. Sociology of Education. Athens: Metechmio (in Greek).

Bocock, Robert. 1997. Consumption: Key Ideas. London: Routhledge.

Braverman, Harry. 1974. Labor and Monopoly Capital: The Degradation of Work in the Twentieth Century. New York: Monthly Review Press.

Breed, Warren. 1958. Mass Communication and Socio-Cultural Integration. Social Forces 37 (2): 109-116.

Brown, Doug. 1992. Doing Social Economics in a Postmodern World. Review of Social Economy 50 (4): 383-403.

Burawoy, Michael. 1979. Manufacturing Consent. Changes in the Labour Process under Monopoly Capitalism. Chicago: Chicago University Press.

Castells, Manuel. 1991. The Informational City. Information Technology, Economic Restructuring and the Urban-Regional Process. Oxford: Blackwell.

Castells, Manuel. 1996. The Rise of the Networked Society. Oxford, UK: Blackwell.

Chadler, James Jr. 1994. Scale and Scope. The Dynamics of Industrial Capitalism. Harvard: Harvard University Press.

Charalambis, Dimitris. 1983. Clientelism and Populism. Athens: Exandas (in Greek).

Cook, Phillip. 1990. Back to the Future. Modernity, Postmodernity and Locality. Winchester, MA: Unwin Hyman.

Coriat, Benjamin. 1997 Globalization. Variety and Mass Production. In Contemporary Capitalism: The Embeddedness of Institutions, edited by Roger Hollingsworth and Robert Boyer, 240-264. Madison, WI: University of Wisconsin.

Curran, James. 1979. Capitalism and Control of the Press, 1800-1975. In Mass Communication and Society edited by James Curran, Michael Gurevitch, and Janet Woollacott, 7-11. Beverly Hills: Sage.

Davis, Stanley. 2001. Management: Managing the Future Now. London: Simon and Schuster.

Debord, Guy. 1986. The Society of Spectacle. Athens: Eleftheros Typos (in Greek).

Demertzis, Nikos. 2002. Political Communication. Risk, Publicity, Internet. Athens: Papazisis (in Greek).

Elam, Mark. 2000. Puzzling out the Post-Fordist Debate: Technology, Markets and Institutions. In Post-Fordism. A Reader, edited by Ash Amin, 43 - 70. Oxford: Blackwell. Engels, Friedrich. 1978a. Letter to Paul Ernst. In Collected Works of Karl Marx and Engels Friedrich, Vol. 10, 426 - 428. Sofia: Partizdat (In Bulgarian).

Engels, Friedrich. 1978b. Letter to Conrad Schmidt. In Collected Works of Karl Marx and Engels Friedrich, Vol. 10, 435 442. Sofia: Partizdat (In Bulgarian).Ewen, Stuart. 1999. All Consuming Images. New York: Basic Books.

Esping-Andersen. Gøsta (1990). The Three Worlds of Welfare Capitalism. Princeton: Princeton University Press.

Esping-Andersen. Gøsta. (1999). Social Foundations of Post-Industrial Economies. New York: Oxford University Press.

Ewen, Stuart. 2001. Captains of Consciousness. Advertising and the Social Roots of the Consumer Culture. New York: Basic Books.

Enzensberger, Hans Magnus. 1981. Toward a Theory of Mass Media. Athens: Epikouros (in Greek).

Fairclough, Norman. 1995. Media Discourse. London: Edward Arnold.

Fuchs, Christian. 2010a. Grounding Critical Communication Studies: An Inquiry into The Communication Theory of Karl Marx. Journal of Communication Inquiry 34 (15): 15-41.

Fuchs, Christian. 2010b. Labor in Informational Capitalism and on the Internet. The Information Society 26 (3): 179-196.

Garnham, Nicholas. 1979. Contribution to A Political Economy Of Mass-Communication. Media, Culture \& Society 1 (2): 123-146.

Garnham, Nicholas. 2003. Emancipation, the Media and Modernity. Athens: Kastaniotis (in Greek).

Gartman, David. 1998. Postmodernism; Or the Cultural Logic of Post-fordism? The Sociological Quarterly 39 (1): 119-137. 
Gerbner, George. 1967. Mass media and Human Communication Theory. In Human Communication theory, edited by Frank Dance, 40-57. New York: Holt, Rinehart and Winston.

Golding, Peter and Graham Murdock. 2001. Culture, Communication and Poltical Economy. In Mass Media and Society, edited by James Curran and Michael Gurevitch, 25-52. Athens: Patakis (in Greek).

Green, Bill, Joe-Ann Reid, and Chris Bigum. 1998. Teaching the Nintendo Generation? Children, Computer Culture and Popular Technologies. In Wired Up: Young People and the Electronic Media, edited by Sue Howard, 19-41. London: UCL Press.

Gualerzi, Davide. 2010. The Coming of Age of Information Technologies and the Path of Transformational Growth. A LongRun Perspective in the Late 2000s Recession. New York: Routledge.

Hall, Stewart. 1980. Encoding/Decoding. In Culture, Media, Language, edited by Stewart Hall, Dorothy Hobson, Andrew Lowe and Paul Willis, 507-517. London: Hutchinson, 1980.

Hamnet, Chris. 1989. Consumption and Class in Contemporary Britain. In The Changing Social Structure, edited by Chris Hamnet, Linda McDowell and Phillipe Sarre, 199-213. London: Sage.

Harris, Jess and Catherine McDonald. 2000. Post-Fordism, the Welfare State and the Personal Social Services: A Comparison of Australia and Britain. The British Journal of Social Work 30 (1): 51-70.

Harvey, David. 1989. The Condition of Postmodernity. An Inquiry into the Origins of Cultural Change, Cambridge: Blackwell.

Herman, Edward and Noam Chomsky. 2001. A Propaganda Model. In Media and Cultural studies. Keyworks, edited by Meenakshi Durham and Douglas Kellner, 180-217. Oxford: Blackwell.

Hickox, Mike and Moore, Robert.1992. Education and post-Fordism: A New Correspondance? In Education for Economic Survival: From Fordism to Post-Fordisim, edited by Phillip Brown and Hugh Laude, 95-116. London: Routledge.

Hill, Annette. 2007. Restyling Factual TV. London: Routledge.

Hirst, Paul and Jonathan Zeitlin. 1991. Flexible Specialization versus Post-Fordism: Theory, Evidence and Policy Implications. Economy and Society 20 (1): 1-156.

Hobsbawm, Eric. 1978. The Forward March of Labour Halted? Marxism Today, September: 279-286.

Hobsbawm, Eric. 2008. The Age of Revolutions. 1789-1848. Athens: Cultural Institute of National Bank (in Greek)

Holloway, John. 2006. Change the World without Taking Power. The Meaning of Revolution Today. Athens: Savalas (in Greek).

Horkheimer, Max and Theodor Adorno. 1986. The Dialectics of Enlightenment. Athens: Ypsilon/books (in Greek).

Horkheimer, Max. 1976. Traditional and Critical Theory. In Critical Sociology: Selected Readings, edited by Paul Connerton. Harmondsworth: Penguin.

Jameson, Fredric. 1984. Postmodernism or the Cultural Logic of Late Capitalism. New Left Review 146: 59-92.

Jessop, Bob. 1990. State Theory. Putting Capitalist Economies in their Place. Cambridge: Polity.

Jessop, Bob and Ngai-Ling Sum. 2006. Beyond the Regulation Approach. Putting Capitalist Economies in their Place. Cheltenham: Edward Elgar Publishing. J

Jessop, Bob. 1994. The Transition to Post-Fordism and the Schumpeterian Workfare State. In Towards a Post-Fordist Welfare State?, edited by Brian Loader and Roger Burrows,13-17. London: Routledge.

Jessop, Bob. 2002. The Future of the Capitalist State. Cambridge: Polity Press.

Kazakos, Panos. 2001. Between State and the Market. Economic Policy after War in Greece 1944-2000. Athens: Patakis (1n Greek).

Kennett, Patricia. 2003. Exclusion, Post-Fordism and the "New Europe". In A New Europe? Economic Restructuring and Social Exclusion, edited by Phillip Brown and Rosemary Crompton, 14-32. London: Routldege.

Lash, Scott and Paul Bagguley. 1988. Labour Relations in Disorganized Capitalism: A Five-Nation Comparison. Environment and Planning D: Society and Space 6 (3): 321-338.

Lambrakou, Zoi. 2011. New Social Movements in the Age of the Internet. The Case of Collective Action with the Use of New Media in Greece 2007-2011. Unpublished MA thesis. Athens: Department of Communication and Media Studies (in Greek).

Lash, Scott and Celia Lury. 2007. Global Culture Industry. The Mediation of Things. Malden MA: Polity.

Lash, Scott and John Urry. 1987. The End of Organized Capitalism. Madison, WI: The University of Wisconsin Press.

Lash, Scott and John Urry. 1994. Economies of Signs and Space. London: Sage.

Lipietz, Alain. 1990. Mirages and Miracles. Athens: Exandas (in Greek).

Lipietz, Alain. 1994, Post-Fordism and Democracy. In Post-Fordism: a Reader, edited by Ash Amin, 251-279. Massachusetts: Blackwell.

Lipietz, Alain. 1997. The Post-Fordist World: Labour Relations, International Hierarchy and Global Ecology. Review of International Political Economy 4 (1): 1 - 41.

Loader, Brian and Roger Burrows. 1994. Towards a Post-Fordist Welfare State? The Restructuring of Britain, Social Policy and the Future of Welfare. In Towards a Post-Fordist welfare state?, edited by Brian Loader and Roger Burrows, 1 - 13. 
London: Routledge.Lyrintzis, Christos, Ilias Nikolakopoulos, and Dimitiris Sotiropoulos, 1996. Introduction. In Society and Politics: Aspects of the Third Greek Republic 1974-1994, edited by Christos Lyrintzis, llias Nikolakopouloa and Dimitiris Sotiropoulos, 19-42. Athens: Greek Society of Political Science and Themelio Publishing (in Greek).

Mann, Michael. 1986. The Sources of Social Power: A History of Power from the Beginning to A.D. 1760. Vol. I. Cambridge: Cambridge University Press.

Manovich, Lev. 2001. The Language of New Media. Cambridge, MA: MIT Press, Marion.Marglin, Stephen and Amit Bhaduri. 1990. Profit Squeeze and Keynesian Theory. In The Golden Age of Capitalism. Reinterpreting the Postwar Experience, edited by Stephen Marglin and Huliet Schor, 153-186. Oxford: Chalderon Press

Marx, Karl and Engels Friedrich. 1975. For the Art. Athens: Exandas (in Greek).

Marx, Karl and Engels Friedrich. 1978. The German Ideology, Vol. 1. Athens: Gutenberg (in Greek).

Marx, Karl and Engels Friedrich. 2001. The Ruling Class and the Ruling Ideas. In Media and Cultural studies. Keyworks, edited by Meenakshi Durham and Douglas Kellner, 39-42. Oxford: Blackwell.

Marx, Karl. 1978a. Towards a Critique of the Political Economy. In Collected Works of Karl Marx and Friedrich Engels, Vol. 7, 113-291. Sofia: Partizdat (In Bulgarian).

Marx, Karl. 1978b. Letter to Franz Mering. In Collected Works of Karl Marx and Engels Friedrich, Vol. 10, 477 - 472 . Sofia: Partizdat (In Bulgarian).

Marx, Karl. 1979. Capital. Sofia: Partizdat (in Bulgarian).

Marx, Karl. 1983. Pre-capitalist Economic Formations. Athens: Kalvos (In Greek).

Matsuyama, Kiminori. 2002. The Rise of Mass Consumption Societies. Journal of Political Economy 110 (5): 1035-1070.

McCracken, Grant. 1988. Culture and Consumption: New Approaches to the Symbolic Character of the Consumer Goods and Activities. Bloomington, IN: Indiana University Press.

Mosco, Vincent. 2009. The Political Economy of Communication. London: Sage. 2nd ed.

Mouriki, Aliki. 1994. Politics of Reform and New Forms of Organization of the Labour. Contemporary Issues, vol. 54 (in Greek).

Mouzelis, Nicos. 2008. Modern, Postmodern Social Theorizing. Bridging the Divide. Cambridge: Cambridge University Press.

Parker, Martin. 2000. The Sociology of Organizations and the Organization of Sociology: Some Reflections on the Making of a Division of Labour. The Sociological Review 48 (1): 124-146.

Perniola, Mario. 1991. The Society of Simulacra. Athens: Alexandria (in Greek).

Plamenatz Petrov, John. 1963. Man and Society. London: Longman.

Pleios George. 2004. Labour and Meaning in Late Modernity: The Significance of Education and the Culture of Image. Review of Social Research, B2004(114): 61-87 (in Greek).

Pleios, George. 1993. Moving Image and Artistic Communication. Athens: Delphini (in Greek).

Pleios, George. 1996. The Crisis of Education in Mature Capitalism. The Tribune of Social Sciences 19: 143-185 (in Greek). Pleios, George. 2001. The Discourse of Image. Ideology and Politics. Athens: Papazisis (in Greek).

Pleios, George. 2011. The Society of Pleasant Information. Modernity and the News. Athens: Kastaniotis (in Greek).

Polanyi, Karl. 2001. The Great Transformation. Boston: Beacon Press.

Pond, Chris. 1989. The Changing Distribution of Income, Wealth and Poverty. In The Changing Social Structure, edited by Chris Hamnet, Linda McDowell and Phillipe Sarre, 43-77. London: Sage.

Poster, Mark. 1990. The Mode of Information: Poststructuralism and Social Context. Chicago: Chicago University Press.

Poulet, Bernard. 2009. The End of Newspapers and the Future of Information. Athens: Polis (in Greek).

Richta, Radovan. 1976. Civilization at Crossroads. Athens: Rappas (in Greek).

Robins, Kevin and Frank Webster. 1988. Cybernetic Capitalism: Information, Technology, Everyday Life. In The Political Economy of Information, edited by Vincent Mosco and Janet Wasko, 44-75. Madison: University of Wisconsin.

Rueschemeyer, Dietrich. 1986. Power and the Division of Labor. Polity Press.

Russell, James. 2006. Double Standard. Lanham, MD: Rowman and Littlefield Publishers.

Sakellaropoulos, Theodoros. 1992. State and Social Interests during the '80s. Athens: Kritiki (in Greek)

Sassen, Saskia. 2009. A Sociology of Globalization. Athens: Metechmio (in Greek).

Schiller, Herbert. 1973. The Mind Managers. Boston: Beacon Press.

Schultz, Theodore. 1961. Investment in Human Capital. The American Economic Review 51 (1): 1- 17.

Sennett, Richard. 2008. The Culture of the New Capitalism. Athens: Savalas (in Greek).

Terranova, Tiziana 2004. Network Culture. Politics for the Information Age. London: Pluto Press.

Thompson, John. 1995. The Media and Modernity. Cambridge: Polity Press.

Thursfield, Denise. 2003. Post-Fordism and Skill: Theories and Perceptions. Burlington: Ashgate.

Thussu, Daya Kissan. 2007. News as Entertainment. The Rise of Global Infotainment. London: Sage.

Toffler, Alvin. 1982. The Third Wave. Athens: Cactos (In Greek). 
Tsoukalas, Konstantinos. 1983. Tradition and Modernity. Some General Issues. In Hellenism and Greekness, edited by Demetrios Tsatsos, 37-48. Athens: Estia.

Vallas, Steven.1999. Rethinking Post-Fordism: The Meaning of Workplace Flexibility. Sociological Theory 17 (1): 68-101. Vergopoulos. Kostas. 1999. Globalization. The Great Mirage. Athens: Nea Synora (in Greek).

Webster, Frank. 1995. Theories of the Information Society. London: Routledge.

Wernick, Andrew.1991. Promotional Culture: Advertising, Ideology and Symbolic Expression. Thousand Oaks, CA: Sage. Williams, Raymond. 1978. Marxism and Literature. Oxford: Oxford University Press.

Williams, Raymond. 2001. Base and Superstructure in Marxist Cultural Theory. In Media and Cultural Studies. Keyworks, edited by Meenakshi Durham and Douglas Kellner, 152-165. Oxford: Blackwell.

Williams, Rosalind. 1991. Dream Worlds: Mass Consumption in Late Nineteenth-Century France. Berkeley and Los Angeles, CA: University of California Press.

Wood, Ellen M. 1997. Modernity, Postmodernity or Capitalism?, Review of International Political Economy 4 (3): 539-560.

\section{About the Author}

George Pleios:

Associate Professor and Head of the Faculty of Communication and Media Studies at the University of Athens, Greece, and director of the Laboratory for Social Research in Mass Media. He is author of 5 books, 13 chapters in edited books, coeditor of 1 book and author of more than 40 articles which have been published in Greek and internationally. In his recent work "The society of pleasant information", he examines the relations between the news and modernity and especially analyses news culture in late modernity. He has been primary investigator in more than 20 research projects and has presented about 50 papers in national and international conferences. His current interests are focusing on the relations between consumer capitalism, ideology and visual culture. 